\title{
EFFECT OF PROCESS PARAMETERS ON SURFACE ROUGHNESS OF NICKEL BASED ALLOYS IN WEDM
}

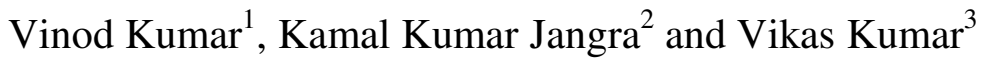 \\ ${ }^{1,3}$ Department of Mechanical Engineering, YMCA University of Science and \\ Technology, Faridabad, Haryana, India \\ ${ }^{2}$ Dept. of Mechanical Engineering, PEC University of Technology, Chandigarh, India
}

\begin{abstract}
In contrast to conventional machining process, WEDM may be proved more economic and efficient in precise machining of wide range of materials ranging from die steel to the high temperature resistance super alloys. In this study, the effect of WEDM process parameters like peak current (Ip), pulse on time (Ton), pulse off time (Toff) and servo voltage (V) on the surface roughness has been considered while machining of Nimonic 90 and Monel 400 using Taguchi's method. Using Taguchi's L18 orthogonal array, process parameters were investigated for surface roughness. Analysis of variance shows that Ton and Ip are highly significant process parameters for surface roughness.
\end{abstract}

\section{KEYWORDS}

WEDM, Nimonic-90, Monel-400, Taguchi method, Surface roughness.

\section{INTRODUCTION}

Nickel based super alloys are growing class of exotic materials which is potentially used in the manufacturing of components for aerospace engine in gas turbine compartments and other applications such as sub marine equipment's, nuclear reactors, petrochemical plants, aircraft gas turbines components, medical equipments e.g. dentistry uses, prosthetic devices and orthopaedic application, etc. [1-2]. Aerospace industries are the main consumer of nickel based alloys because they possess excellent mechanical and chemical properties at very high temperature.

Nickel based alloys may contain the constituents of chromium, aluminium, titanium, cobalt, molybdenum and other elements in varying quantity to give their outstanding high temperature strength and extreme toughness which create difficulties during machining and resulting in development of very high cutting forces [3-4]. Conventional machining of these material forms a built layer on cutting tool face, which results poor surface integrity and higher crater wear involving several surface defects such as, material pull-out/cracking, surface drag, tearing surface, etc. [5-9]. These surface defects significantly lower the fatigue life of nickel based aerocomponents.

WEDM is a non-conventional machine and proved more efficient and economic for machining complex and difficult geometries in high hardness and high heat resisting materials with high accuracy. Several attempts have been made on EDM and WEDM. Machining of Hastelloy-X with EDM, Pulse on time (Ton) is the main process parameter affects the surface integrity of the work surface [10]. The most influential factor on MRR is peak current (Ip) and duty factor. High value of Ip is suggested for obtaining high MRR during the EDM of Inconel 718 with hollow

DOI : 10.14810/ijmech.2015.4408 
tools [11]. Machining of Inconel 718 using EDM with a copper electrode, Taguchi technique is used to analysis the effect of each process parameter, i.e., peak current (Ip), Ton, gap voltage and duty cycle on machining performances such material removal rate (MRR), electrode wear rate (EWR), radial over cut (RoC) and half taper angle. Ip significantly affects the MRR and Ton significantly affects the EWR [12].

Singh et al. [13] investigated the effect of WEDM process parameters namely, Toff, Ton, servo voltage $(\mathrm{SV})$, Ip, wire feed rate $\left(\mathrm{W}_{\mathrm{F}}\right)$ and Wire tension $\left(\mathrm{W}_{\mathrm{T}}\right)$ on MRR of hot die steel $(\mathrm{H}-11)$ with one variable at a time approach. It is concluded that MRR is directly decreases with increase in Toff and SV and increases with increase in Ton and Ip. Kumar et al. [14] reported the effect of four inputs WEDM parameters such as, Ip, Ton, Toff and SV and modeled for two performance characteristics, i.e., MRR and surface roughness (SR). The effect of process parameters is analysed using response surface graphs. Result showed that surface finish may be enhanced efficiently using single trim cut at low discharge energy with appropriate wire off-set value. Jangra et al. [15] presented an experimental study of rough and trim cutting operation of Nimonic 90 with three different materials, i.e., Die steel, Tungsten carbide composite and Monel 400 in WEDM. Results suggested that surface characteristics may be improved using single trim cut with optimal machining parameters and correct wire offset, irrespective the high discharge energy of rough cut. Using Gray-Taguchi method, WEDM process parameters of Incoloy 800 super alloy are optimised for multiple machining performances, i.e., MRR, SR and kerf [16].

Based on preliminary experiments on WEDM of Nimonic-90 and Monell 400, it is found that effective working range of pulse-on time is $106 \mu$ s to $118 \mu \mathrm{s}$. Beyond $118 \mu \mathrm{s}$ at Toff below $35 \mu \mathrm{s}$, breakage of wire electrode occurs frequently. Effect of peak current (Ip) is noticeable only from $70 \mathrm{~A}$ to $160 \mathrm{~A}$, therefore, an effective range of $90 \mathrm{~A}$ to $150 \mathrm{~A}$ has been selected for Ip. Similarly for $\mathrm{SV}$ an effective range of $30 \mathrm{~V}$ to $50 \mathrm{~V}$ has been selected that provide a noticeable variation in machining performance. In present study two Nickels based alloy Nimonic 90 (Nickel Chromium - Cobalt alloy) and Monel 400 (Nickel - Copper alloy) are taken as work materials. Effect of machining parameters namely; Toff, Ton, Ip and SV are evaluated on SR in WEDM using Taguchi's design of experiment. An optimal setting of machining parameters is obtained for minimising the surface roughness in WEDM of Nickel alloys.

\section{EXPERIMENTAL PROCEDURE}

\subsection{Experimental procedure}

A 5 axis sprint cut (ELPUSE-40) WEDM is used for experimental work, manufactured by Electronic M/C Tool LTD India (Figure 1). Copper coated brass wire of diameter $0.25 \mathrm{~mm}$ is used. Distilled water as a dielectric fluid is used with conductivity $20 \mu \mathrm{S} / \mathrm{cm}$. $\mathrm{W}_{\mathrm{F}}$ is kept constant value of $5 \mathrm{~m} / \mathrm{min}$. Wire off set is taken at zero value. The chemical composition and mechanical properties of Nimonic 90 and Monel 400 work-piece materials used in the experiments in the form of a rectangular sheet of $12.5 \mathrm{~mm}$ thickness are shown in Tables 1 . 
Table 1: Chemical composition and mechanical properties of Nickel based alloys

\begin{tabular}{|c|c|c|c|c|c|}
\hline $\begin{array}{c}\text { Work } \\
\text { Material }\end{array}$ & $\begin{array}{c}\text { De } \\
\text { nsit } \\
y\end{array}$ & Melting point & $\begin{array}{l}\text { Co-efficient of } \\
\text { Expansion }\end{array}$ & $\begin{array}{l}\text { Modulus of } \\
\text { Rigidity }\end{array}$ & $\begin{array}{l}\text { Modul } \\
\text { us of } \\
\text { Elastic } \\
\text { ity }\end{array}$ \\
\hline $\begin{array}{c}\text { Nimonic } \\
\text { 90(wt \%) } \\
(\mathrm{Ni} 60, \mathrm{Cr} \\
\text { 19.3,Co } 15, \\
\text { Ti 3.1, Al } 1.4 \\
\text { ) }\end{array}$ & $\begin{array}{c}8.1 \\
8 \\
\mathrm{~g} / \mathrm{c} \\
\mathrm{m}^{3}\end{array}$ & $1370^{\circ} \mathrm{C}$ & $12.7 \mu \mathrm{m} / \mathrm{m}^{0} \mathrm{C}$ & $82.5 \mathrm{KN} / \mathrm{mm}^{2}$ & $\begin{array}{c}213 \mathrm{KN} \\
/ \mathrm{mm}^{2}\end{array}$ \\
\hline $\begin{array}{c}\text { Monel } \\
\text { 400(wt \%) } \\
(\mathrm{Ni} 63.47, \\
\mathrm{Cu} \mathrm{33,} \mathrm{Fe} \\
2.13, \mathrm{Mn} 1)\end{array}$ & $\begin{array}{l}8.8 \\
\mathrm{~g} / \mathrm{c} \\
\mathrm{m}^{3}\end{array}$ & $1350^{\circ} \mathrm{C}$ & $13.9 \mu \mathrm{m} / \mathrm{m}^{0} \mathrm{C}$ & $\begin{array}{c}65.3 \\
\mathrm{KN} / \mathrm{mm}^{2}\end{array}$ & $\begin{array}{c}115 \\
\mathrm{KN} / \mathrm{m} \\
\mathrm{m}^{2}\end{array}$ \\
\hline
\end{tabular}

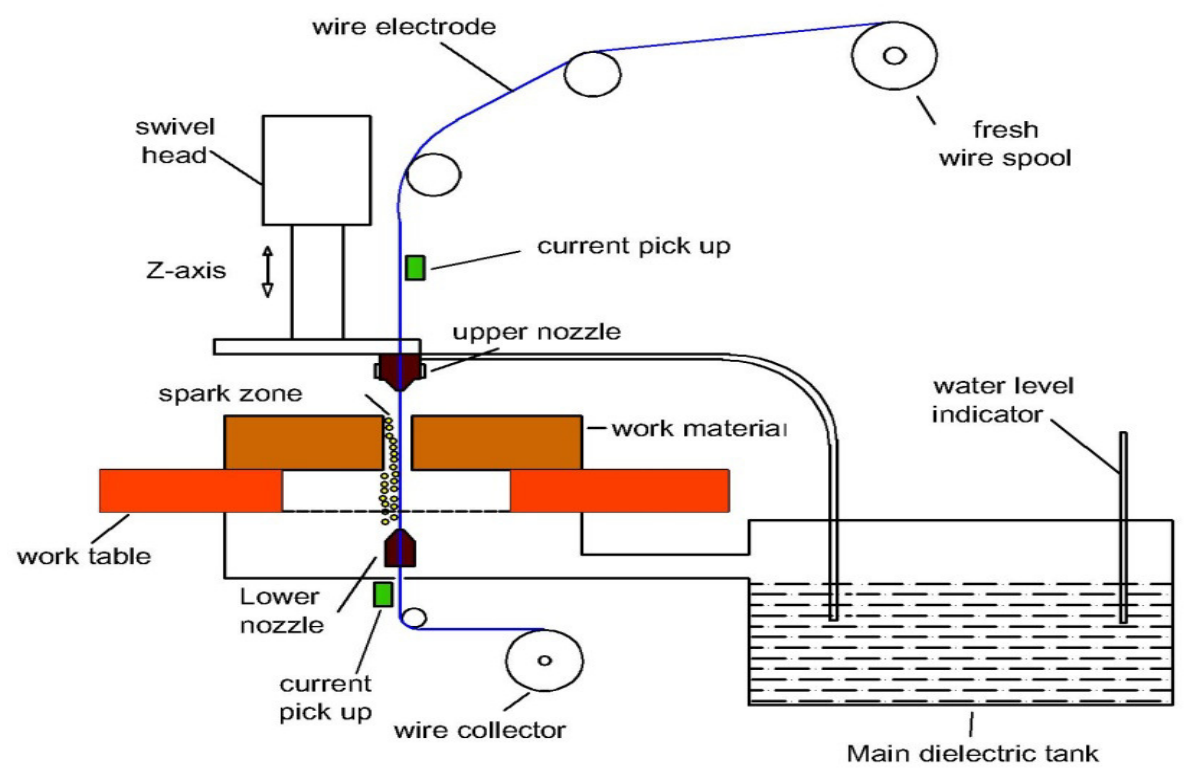

Figure1. Schematic Representation of WEDM Process

\subsection{Experimentation Methodology}

In present work, five process parameters have been chosen for investigation such as work materials (M), Ip, Ton, Toff, and SV. Table 2 shows the selected parameters and their levels. $\mathrm{L}_{18}$, orthogonal array is selected in present work to conduct the experimentation. Experiment plan is listed in Table 3. 
Table 2: Machining parameters and their levels

\begin{tabular}{|c|l|c|c|c|c|}
\hline Symbol & \multicolumn{1}{|c|}{$\begin{array}{c}\text { Machining } \\
\text { Parameter }\end{array}$} & Units & Level 1 & Level 2 & Level 3 \\
\hline A & Material (M) & ---- & Monel-400 & Nimonic-90 & --- \\
\hline B & Peak Current (Ip) & A & 90 & 120 & 150 \\
\hline C & Pulse on Time (Ton) & $\mu \mathrm{s}$ & 106 & 112 & 118 \\
\hline D & Pulse off Time (Toff) & $\mu \mathrm{s}$ & 35 & 40 & 45 \\
\hline E & Servo voltage (SV) & V & 30 & 40 & 50 \\
\hline
\end{tabular}

\subsection{Experimental Results}

Based on the experimental layout shown in Table 3, the experiments are performed. The SR (Rmax. $\mu \mathrm{m}$ ) of machined surface is measured by using the digital surface tester Mitutoyo 201P. Measured surface roughness characteristics are shown in Table 4. Residual plot for mean surface roughness are shown in Figure 2.

Residual plots are used to assess the data for the problems like non-random variation, nonconstant variance, non normality and higher-order relationships. Figure 2 show that the residuals follow an approximately straight line in normal probability plot. Approximate symmetric nature of histogram referred that the residuals are normally distributed.

Table 3: Experimental layout using an L18 orthogonal array

\begin{tabular}{|c|c|c|c|c|c|}
\hline & \multicolumn{5}{|c|}{ Machining parameters } \\
\hline Exp No. & $\begin{array}{c}\text { A } \\
\text { Material } \\
\text { type }\end{array}$ & $\begin{array}{c}\text { B } \\
\text { Peak } \\
\text { current }\end{array}$ & $\begin{array}{c}\text { Culse on } \\
\text { time }\end{array}$ & $\begin{array}{c}\text { D } \\
\text { Pulse off } \\
\text { time }\end{array}$ & $\begin{array}{c}\text { E } \\
\text { Servo } \\
\text { voltage }\end{array}$ \\
\hline 1 & Monel-400 & 90 & 106 & 35 & 30 \\
\hline 2 & Monel-400 & 90 & 112 & 40 & 40 \\
\hline 3 & Monel-400 & 90 & 118 & 45 & 50 \\
\hline 4 & Monel-400 & 120 & 106 & 35 & 40 \\
\hline 5 & Monel-400 & 120 & 112 & 40 & 50 \\
\hline 6 & Monel-400 & 120 & 118 & 45 & 30 \\
\hline 7 & Monel-400 & 150 & 106 & 40 & 30 \\
\hline 8 & Monel-400 & 150 & 112 & 45 & 40 \\
\hline 9 & Monel-400 & 150 & 118 & 35 & 50 \\
\hline 10 & Nimonic-90 & 90 & 106 & 45 & 50 \\
\hline 11 & Nimonic-90 & 90 & 112 & 35 & 30 \\
\hline 12 & Nimonic-90 & 90 & 118 & 40 & 40 \\
\hline 13 & Nimonic-90 & 120 & 106 & 40 & 50 \\
\hline 14 & Nimonic-90 & 120 & 112 & 45 & 30 \\
\hline 15 & Nimonic-90 & 120 & 118 & 35 & 40 \\
\hline 16 & Nimonic-90 & 150 & 106 & 45 & 40 \\
\hline 17 & Nimonic-90 & 150 & 112 & 35 & 50 \\
\hline 18 & Nimonic-90 & 150 & 118 & 40 & 30 \\
\hline
\end{tabular}




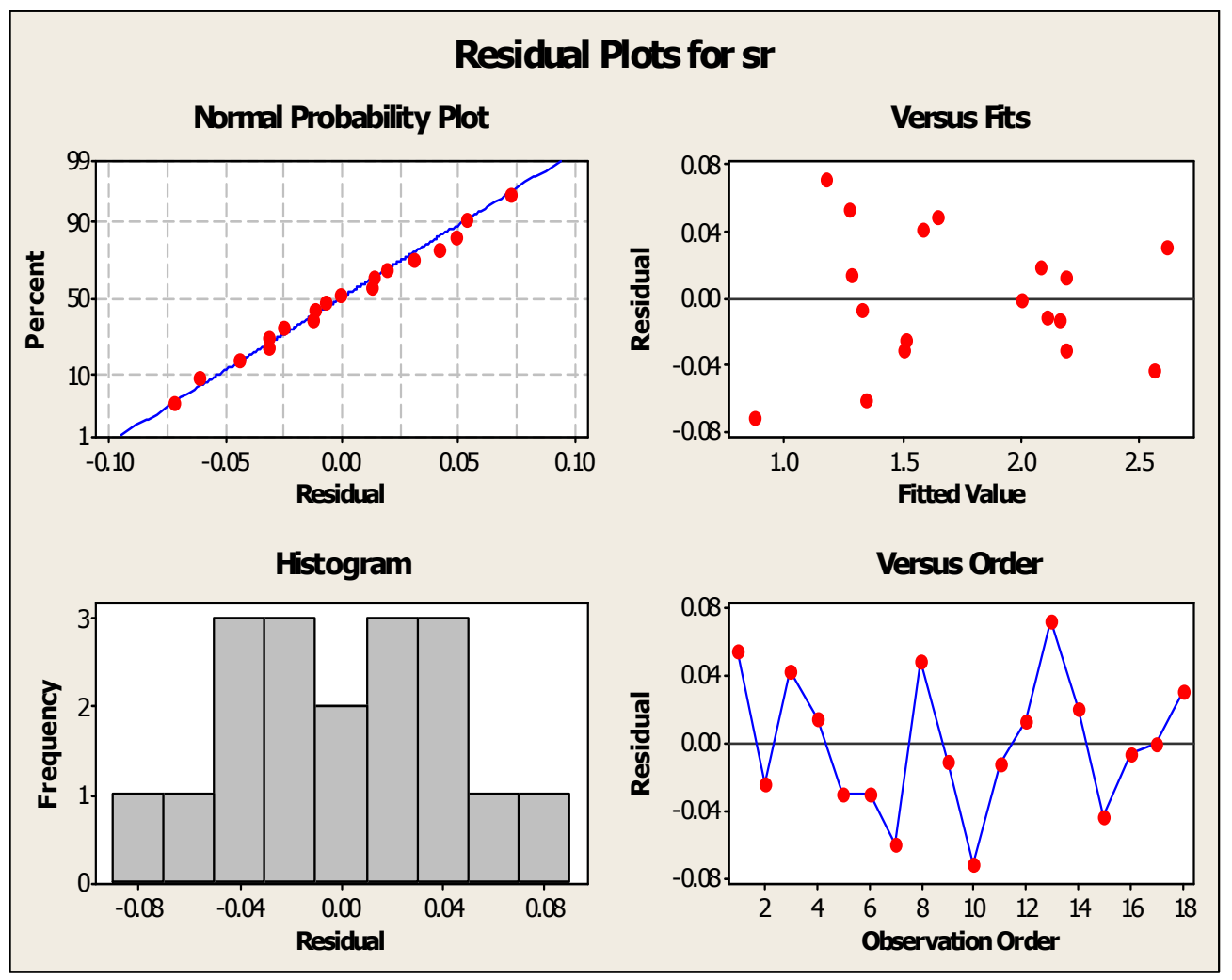

Figure 2. Residual Plot for Mean Surface Roughness

\section{RESULT AND DISCUSSION}

The $\mathrm{S} / \mathrm{N}$ ratio may be used to measured deviation of the performance characteristics from the desired value in Taguchi method, so that the experimental results are changed into a signal to noise $(\mathrm{S} / \mathrm{N})$ ratio. The aim of using the $\mathrm{S} / \mathrm{N}$ ratio is to determine the performance to develop products and processes insensitive to noise factors. There are three types of $\mathrm{S} / \mathrm{N}$ ratio, i.e., lower the better, higher the better and nominal the better. In present work, lower the better is selected for SR. Table 4 shows the $\mathrm{S} / \mathrm{N}$ ratio and measured mean values of SR.

$\mathrm{S} / \mathrm{N}$ for lower the better

$\mathrm{S} / \mathrm{N}$ ratio $\eta=10 * \log \left(1 / \sum_{\mathrm{i}=1}^{\mathrm{n}} \frac{1}{y_{i j}^{2}}\right)$

Where $n=$ repeated number of experiments

$y_{i j}=$ observed machining experiment response value

Where $\mathrm{i}=1,2,3, \ldots \ldots, \mathrm{n} \quad \mathrm{j}=1,2,3, \ldots \ldots ., \mathrm{k}$ 
Table 4: Mean value and S/N ratio of Surface Roughness

\begin{tabular}{|c|c|c|}
\hline $\begin{array}{c}\text { Experiment } \\
\text { No. }\end{array}$ & SR $(\boldsymbol{\mu m})$ & $\begin{array}{c}\text { (S/N ratio }) \\
\text { SR }\end{array}$ \\
\hline 1 & 1.33 & -2.47703 \\
\hline 2 & 1.49 & -3.46373 \\
\hline 3 & 1.63 & -4.24375 \\
\hline 4 & 1.3 & -2.27887 \\
\hline 5 & 1.47 & -3.34635 \\
\hline 6 & 2.16 & -6.68908 \\
\hline 7 & 1.28 & -2.1442 \\
\hline 8 & 1.7 & -4.60898 \\
\hline 9 & 2.1 & -6.44439 \\
\hline 10 & 0.8 & 1.9382 \\
\hline 11 & 2.15 & -6.64877 \\
\hline 12 & 2.2 & -6.84845 \\
\hline 13 & 1.25 & -1.9382 \\
\hline 14 & 2.1 & -6.44439 \\
\hline 15 & 2.52 & -8.02801 \\
\hline 16 & 1.32 & -2.41148 \\
\hline 17 & 2 & -6.0206 \\
\hline 18 & 2.65 & -8.46492 \\
\hline Average & 1.747222 & \\
\hline \multicolumn{3}{|l}{} \\
\hline
\end{tabular}

The response table is used to find out the effect of each level of process parameter on SR using Taguchi method. Table 5 shows response table for mean SR.

Table 5: Response Table for Mean SR

\begin{tabular}{|c|c|c|c|c|c|}
\hline Level & $\begin{array}{c}\text { A } \\
\text { Material } \\
\text { type }\end{array}$ & $\begin{array}{c}\text { B } \\
\text { Peak current }\end{array}$ & $\begin{array}{c}\text { C } \\
\text { Pulse on time }\end{array}$ & $\begin{array}{c}\text { D } \\
\text { Pulse off time }\end{array}$ & $\begin{array}{c}\mathbf{E} \\
\text { Servo } \\
\text { voltage }\end{array}$ \\
\hline 1 & 1.607 & 1.600 & 1.213 & 1.900 & 1.945 \\
\hline 2 & 1.888 & 1.800 & 1.818 & 1.723 & 1.755 \\
\hline 3 & --- & 1.842 & 2.210 & 1.618 & 1.542 \\
\hline
\end{tabular}

Figure 3 shows the $\mathrm{S} / \mathrm{N}$ ratio plot for $\mathrm{SR}$. The optimum parameters combination for $\mathrm{SR}$ is A1B1C1D3E3 corresponding to largest values of $\mathrm{S} / \mathrm{N}$ ratio for all process parameters. 


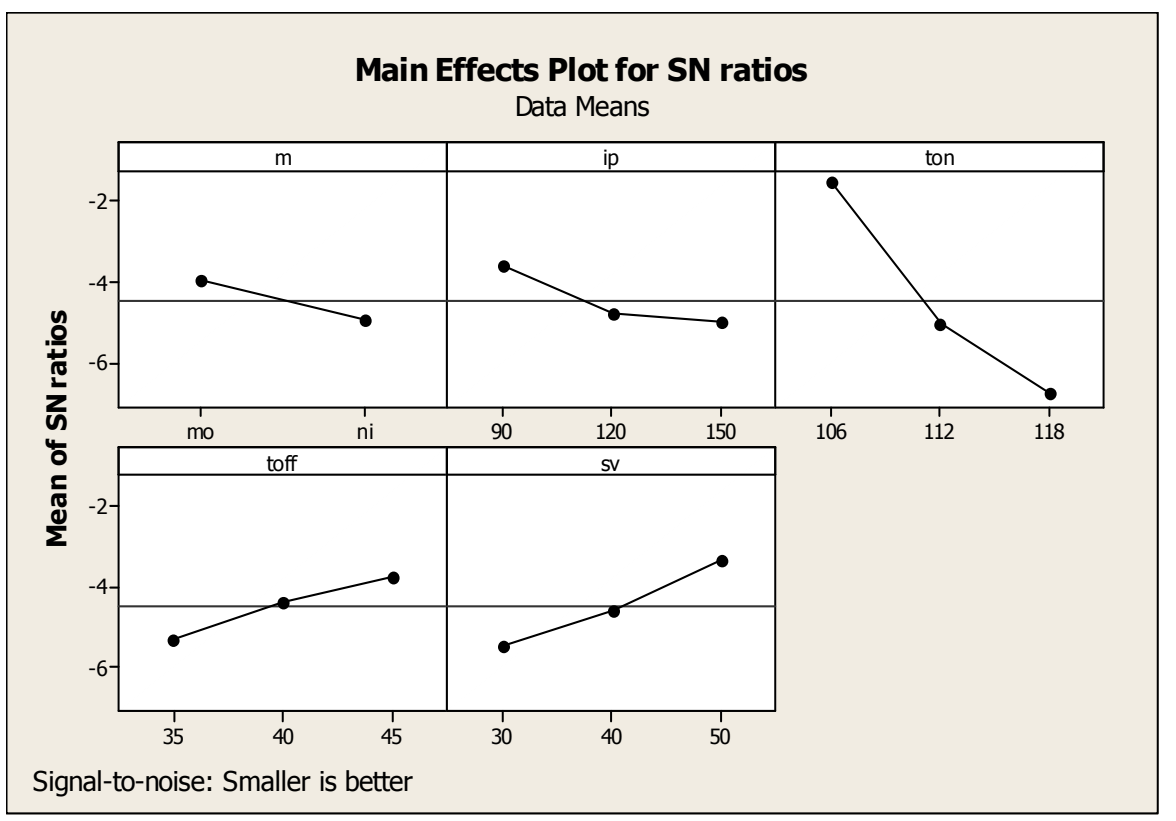

Figure 3. Main Effect Plots for S/N Ratio of Mean Surface Roughness.

\subsection{Analysis Of Variance (ANOVA)}

Using Mini Tab 16, a stastical tool the Analysis of variance (ANOVA) is performed to find out the significant process parameters on SR. Table 6 shows the effect of individual machining parameters (with percentage of contribution). $\mathrm{P}$ value lower than 0.05 implies that parameter is highly significant under $95 \%$ confidence level.

Analysis of variance (ANOVA) is employed to determine only significant parameters in order to predict the optimal values of the machining characteristics. The optimal values are calculated by using the formula.

$\left.\eta_{\text {opti }}=\mathrm{M}+\sum_{i=1}^{m}\left(M_{i, j}\right)_{\max }-M\right)$

$\eta_{\text {opti }}=$ Predicate optimal value

$\mathrm{M}=$ Total mean of $\mathrm{S} / \mathrm{N}$ ratio

$\mathrm{m}=$ number of significant process parameters affecting the machining performance

$\left(M_{i, j}\right)_{\max }=\mathrm{S} / \mathrm{N}$ ratio of optimum level $\mathrm{i}$ of parameter $\mathrm{j}$

Table 6 shows ANOVA for mean surface roughness. It is clear from the Table 6 all these parameters has significantly (since $p$-value $\leq 0.05$ ) affecting the Surface Roughness under $95 \%$ confidence level. Using Eq. (2), the optimum value is calculated as follows,

$\left.\eta_{\text {opti }}=\mathrm{M}+\sum_{i=1}^{m}\left(M_{i, j}\right)_{\max }-M\right)=1.747+(1.607-1.747)+(1.600-1.747)+(1.213-1.747$ )$+(1.618-1.747)+(1.542-1.747)=0.70$ 
Table 6 ANOVA for mean surface Roughness

\begin{tabular}{|c|c|c|c|c|c|c|}
\hline Source & DF & Seq SS & Adj SS & Adj MS & F & P \\
\hline WM & 1 & 0.33561 & 0.35561 & 0.35561 & 102.29 & 0.000 \\
\hline Ip & 2 & 0.20028 & 0.20028 & 0.10014 & 28.81 & 0.000 \\
\hline Ton & 2 & 3.02554 & 3.02554 & 1.51277 & 435.16 & 0.001 \\
\hline Toff & 2 & 0.24314 & 0.24314 & 0.12157 & 34.97 & 0.002 \\
\hline SV & 2 & 0.48858 & 0.48858 & 0.24429 & 70.27 & 0.002 \\
\hline Error & 8 & 0.02781 & 0.02781 & 0.00348 & & \\
\hline Total & 17 & 4.34096 & & & \\
\hline \multicolumn{7}{|c|}{$\mathrm{S}=0.05896 \quad \mathrm{R}-\mathrm{Sq}=99.36 \% \quad \mathrm{R}-\mathrm{Sq}(\operatorname{adj})=98.64 \%$} \\
\hline
\end{tabular}

Confirmatory experiments are conducted for SR corresponding to their optimal setting of process parameters to validate the used approach. Table 7 displays the predicted and experimental values of surface roughness.

Table 7: Optimal values of individual machining characteristics

\begin{tabular}{|c|c|c|c|}
\hline $\begin{array}{c}\text { Machining } \\
\text { Characteristic }\end{array}$ & $\begin{array}{c}\text { Optimal parameters } \\
\text { combination }\end{array}$ & $\begin{array}{c}\text { Predicted } \\
\text { optimal value }\end{array}$ & $\begin{array}{c}\text { Experimental } \\
\text { value }\end{array}$ \\
\hline $\begin{array}{c}\text { Surface } \\
\text { Roughness }\end{array}$ & A1B1C1D3E3 & $0.7 \mu \mathrm{m}$ & $0.8 \mu \mathrm{m}$ \\
\hline
\end{tabular}

\section{CONCLUSIONS}

In this study, machinability of Nimonic 90 and Monel 400 with WEDM has been investigated in term of surface roughness. Taguchi's design of experiment techniques is used to optimized the four process parameters namely Ip, Ton, Toff and SV to achieve minimum surface roughness. The best predicated value for SR is $0.7 \mu \mathrm{m}$. On the basis of result, Taguchi's design of experiment technique is employed to optimize the process variables to achieve minimum SR. ANOVA is used to predict the significant factors affecting the SR. Using ANOVA on experimental results, all of these process parameters namely pulse on time, pulse off time, peak current and servo voltage are found the most significant affecting the SR under 95\% confidence level. SR increases with increasing discharge energy for both work materials. Due to the difference in values of thermal conductivity of both work materials, Monel-400 has a low value of surface roughness as compared to Nimonic 90 for same discharge parameters. Confirmatory experiments show that, using present approach, process parameters are successfully optimized for minimum SR.

With increase of discharge energy results increase of surface roughness of machined surface. Surface finish of nickel based alloys significantly affects the fatigue life of machined aerospace components. The machining parameter Ton, Ip are the main factors that affects the surface roughness of the work material. Machining of Nimonic-90 and Monel 400 with WEDM at optimized setting proves the potential of WEDM in aerospace industries for machining complex and intricate shapes in hard and exotic materials. 


\section{ACKNOWLEDGEMENT}

This research was supported by YMCAUST Faridabad, Haryana. The authors are thankful to all faculty of Mechanical Engineering, YMCAUST Faridabad, for providing the necessary facilities for the preparation of the paper. Finally, I sincerely thank my family for their patience and support.

\section{REFERENCES}

[1] Ezugwu, E.O. (2005) "Key improvements in the machining of difficult-to-cut aerospace superalloys", International Journal of Machine Tools and Manufacture, Vol. 45, pp. 1353-1367.

[2] Choudhury, I.A. and El-Baradie, M.A. (1998) "Machinability of nickel-base super alloys- a general review", Journal of Material Processing Technology, Vol. 77, pp. 278-284.

[3] E.O. Ezugwu, E.O., Wang, Z.M. and Machado, A.R. (1999) "The machinability of Nickel -based alloys -a review", Journal of Material Processing Technology, Vol. 86, pp.1-16.

[4] Kwong, J., Axinte, D.A. and Withers, P.J. (2009) "The sensitivity of Ni-based superalloy to hole making operations: Influence of process parameters on subsurface damage and residual stress", Journal of Materials Processing Technology, Vol. 209, pp. 3968-3977.

[5] Ulutan, D. and Ozel, T. (2011) "Machining induced surface integrity in Titanium and Nickel AlloysA review", Journal of Material Processing Technology, Vol. 51, pp. 250-280.

[6] Kortabarria, A., Arrazola, P.J., Madariaga, A., Fernandez, E. and Esnaola, J.A. (2011) "A comparative study of residual stress profiles on Inconel 718 induced by dry face turning", Procedia Engineering, Vol. 19, pp. 228 - 234.

[7] Herbert, C.R.J., Axinte, D.A., Kwong, J., Kong, M.C., Hardy, M.C. and Wither, P.J. (2012) “An evaluation of the evolution of workpiece surface integrity in hole making operations for a nickelbased superalloy", Journal of Material Processing Technology, Vol. 212, pp. 1723- 1730.

[8] Krain, H.R., Sharman, A.R.C. and Ridgway, K. (2007) "Optimisation of tool life and productivity when end milling Inconel 718TM”, Journal of Material Processing Technology, Vol. 189, pp.153161.

[9] Sharman, A.R.C., Hughes, J.I. and Ridgway, K. (2004) "Workpiece Surface Integrity and Tool Life Issues When Turning Inconel 718 TM Nickel Based Superalloy”, Journal of Machining Science and Technology, Vol. 8(3), pp. 399-414.

[10] Kang, S.H. and Kim, D.E. (2003) "Investigation of EDM Characteristics of Nickel-based Heat Resistant", KSME International Journal, Vol. 17(10), pp.1475-1484.

[11] Rajesha, S., Sharma, A.K. and Kumar, P. (2011) "On Electro Discharge Machining of Inconel 718 with Hollow Tool", Journal of Materials Engineering and Performance, Vol. 21(6), pp. 882-891.

[12] Ghewade, D.V. and Nipanikar, S.R. (2011) "Experimental study of Electro Discharge machining for Inconel material". Journal of Engineering Research and Studies, Vol. 2(2), pp. 107-112.

[13] Singh, H. and Garg, R. (2009) "Effects of process parameters on material removal rate in WEDM", Journal of Achievements in Materials and Manufacturing Engineering, Vol. 32(1), pp. 70-74.

[14] Kumar, V., Kumar, V. and Jangra, K. K. (2015) “An experimental analysis and optimization of machining rate and surface characteristics in WEDM of Monel-400 using RSM and desirability approach", Journal of Industrial Engineering International, Doi: 10.5267/j.ijiec.2015.2.006.

[15] Jangra, K.K., Kumar, V. and Kumar, V. (2014) "An experimental and comparative study on rough and trim cutting operation in WEDM of hard to machine materials", Procedia Material Science, Vol. 5, pp. 1603-1612.

[16] Muthu Kumar, V., Suresh Babu, A., Venkatasamy, R. and Raajenthiren, M. (2010) "Optimization of the WEDM Parameters on Machining Incoloy800 Super alloy with Multiple Quality Characteristics", International Journal of Engineering Science and Technology, Vol. 2(6), pp.1538-1547. 